\title{
A igreja como espaço retórico para o ato da pregação e o fortalecimento do ethos do(a) pastor(a)
}

\section{Elizabeth Rizzi Lyra}

\section{Fabiola Mirella Dias Roque da Silva}

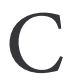
om base nos pressupostos teóricos de Orlandi ${ }^{1}$, Citelli ${ }^{2}$, Perelman e Olbrechts-Tyteca ${ }^{3}$ tem-se neste texto o objetivo de analisar quais lugares retóricos o orador do discurso religioso utiliza para fornecer as provas e, assim, construir o seu ethos. Inicialmente, são apresentadas algumas considerações a respeito das características do discurso religioso e o papel do orador, uma vez que ele fala pela voz da instituição a que pertence. Depois, tecemos algumas considerações acerca dos lugares retóricos como estratégias argumentativas em busca da adesão do auditório, para posteriormente aplicá-las à análise de um recorte do sermão da Pastora Damares Alves, que tematiza a ideologia de gênero.

Pensar em analisar a construção do ethos do pastor pode parecer desnecessário uma vez que ele, como representante religioso, fala por meio de uma instituição e é respeitado em seu meio, mas isso não quer dizer que não exista uma preocupação por parte do orador em legitimar a sua posição

1 Orlandi, 2006.

2 Citelli, 1997.

3 Perelman e Olbrechts-Tyteca, 2014. 
de prestígio. À medida que constrói o discurso durante os sermões, usa de estratégias persuasivas que buscam não só a adesão do auditório, mas também procura mostrar que argumenta por ter conhecimento de causa. É uma busca constante da manutenção de autoridade bem como da legitimidade no discurso.

Mas será que o orador tem autonomia nesse tipo de discurso? Para responder a essa pergunta devemos levar em consideração que há um vasto campo semântico, linguístico e estilístico a ser escolhido por cada orador e essas escolhas, além de construir o ato retórico, edificam o ethos. Ou seja, mesmo que o pastor fale por meio de uma instituição, há escolhas a serem feitas. É ele quem escolhe quais argumentos usará em seu discurso de acordo com a força que pretende designar a cada ideia proferida. No entanto, como já mencionado, isso não quer dizer que não exista uma preocupação com a imagem da Instituição religiosa e que não existam regras a serem seguidas. Toda Igreja, seja católica ou evangélica, tem seus dogmas muitos bem estabelecidos e o orador, mesmo que tenha liberdade na construção de seu discurso, deve ter em mente que esses dogmas precisam prevalecer acima de qualquer opinião individual.

O tema de análise deste trabalho também se justifica pelo fato de o discurso religioso ser atualmente objeto de estudo de várias áreas de conhecimento não só pela razão de sua complexidade, como pelo fascínio que exerce sobre as pessoas. Uma das explicações para esse fascínio está na constante busca por respostas aos dilemas sobre existência humana e, podemos dizer ainda pelos dilemas da vida moderna. Além disso, há ainda o fato de o número de igrejas, em especial as evangélicas, ter crescido muito nos últimos anos, impulsionadas, principalmente, pela facilidade burocrática, ao contrário do que acontece em outras atividades.

Segundo Mafra ${ }^{4}$, o segmento evangélico é identificado como um povo missionário e cristão. Assim, o trabalho exercido dentro da igreja tem como objetivo não só levar a palavra do evangelho, mas também expandir o seu domínio. Dessa forma, o discurso torna-se importante instrumento de propagação e expansão. E resta a pergunta: de que outra maneira as igrejas evangélicas conseguiriam expandir o seu domínio se não por meio do discurso? Embora o fator econômico seja apontado como justificativa principal para o crescimento das igrejas neopentecostais no Brasil, em meio a muitas

4 Mafra, 2001. 
denominações religiosas, o discurso pode ser o diferencial na busca por fieis e, muito mais importante, pela permanência deles.

Um outro motivo do interesse acadêmico pelo tema está relacionado ao cenário político. Edir Macedo, líder da Igreja Universal do Reino de Deus, uma das igrejas que mais crescem no Brasil, por exemplo, incentiva em seus sermões os fiéis a participarem da vida política como forma de manutenção da ordem moral. Escreveu o livro "Plano de Poder: Deus, os cristãos e a política" para esclarecer aos irmãos os temas da política a partir de um ponto de vista bíblico e técnico. E assim o fizeram outras igrejas como, por exemplo, a Assembleia de Deus com o livro: "Irmão vota em Irmão", do assembleiano Josué Sylvestre que segue a mesma linha do livro de Edir Macedo. E tudo isso implica uma mudança do discurso puramente evangelizador que se propõe a "salvar" não só a política, mas, consequentemente, a sociedade dos ataques aos valores da moralidade, da família tradicional e dos "bons costumes".

Também impulsionados pela grade mídia, o discurso religioso precisou se modificar e isso fez com que as Igrejas buscassem alternativas para adequar-se aos aspectos da sociedade moderna. Uma dessas modificações está relacionada à mídia eletrônica, geradora de um fenômeno que Gomes ${ }^{5}$ chama de Midiatização, ou seja, à medida que os meios de comunicação foram se desenvolvendo as instituições religiosas foram se apropriando desses meios como extensão da igreja. A quantidade crescente de programas religiosos na mídia eletrônica evidencia uma grande disputa pelos espaços midiáticos entre algumas das principais denominações religiosas como a Igreja Universal do Reio de Deus, A Igreja Mundial do Poder de Deus, a Batista de Lagoinha, entre muitas outras. Para Klein, "ampliar a voz do evangelho pelos meios eletrônicos de comunicação é, antes de tudo, uma estratégia missionária, o falar com a finalidade de arrebanhar novos fiéis ${ }^{6 "}$.

Sabemos que o discurso religioso tem como finalidade a propagação dos textos bíblicos, no entanto, em meio a uma disputa por fiéis, os aspectos argumentativos ganham destaque maior a cada dia. Com as novas denominações religiosas que surgem, atrair o público e principalmente persuadir o auditório para que ele se torne fiel assíduo da Igreja torna-se o foco principal da instituição, tanto que a meta da Igreja Batista de Lagoinha, objeto de estudo deste trabalho, é alcançar até $2020,10 \%$ da população de cada cidade em que estão localizadas.

Gomes (2008).

6 Klein, 2006, p. 143. 
Enfim, o discurso religioso tem como característica a argumentação. Seus representantes, por meio de atos retóricos, levam multidões aos cultos e missas todos os dias. É, pois, interessante analisar de quais recursos retóricos argumentativos o orador utiliza para construir o seu discurso e consequentemente o seu ethos.

\section{O discurso religioso}

Analisar a constituição do ethos do pastor implica necessariamente compreender como o discurso religioso se configura. Segundo Orlandi ${ }^{7}$ o discurso religioso "é aquele que faz ouvir a voz de Deus ou de seus enviados". Dessa forma, o orador, na figura do padre ou pastor, é visto como uma voz autorizada de Deus. No entanto, o ideal é que não o modifique e siga regras reguladas pelo texto sagrado. É um discurso que não permite mediações ou ponderações. O signo se fecha e irrompe a voz da "autoridade" sobre o assunto, trata-se, portanto, de um tipo de discurso em que a interação é estabelecida de forma a conter a reversibilidade e cujo sentido fica aprisionado pelo próprio dizer: único e inquestionável. Para Citelli ${ }^{8}$ esse fato se dá porque há no discurso religioso predominância do autoritarismo: o orador fala para um auditório que não responde diretamente a suas indagações. O discurso autoritário faz com que as verdades de uma instituição sejam expressão da verdade de todos. Não há outra possibilidade de verdade ou, sequer, de contestação que não seja o que é dito pelo enunciador. Não há espaço no discurso religioso para a troca de informações e/ou opiniões entre os interlocutores.

O discurso autoritário, como característica principal, elimina qualquer possibilidade de interação entre as partes. Neste caso, instauram-se possibilidades de controle sobre o ouvinte. Esta relação entre quem fala e quem recebe o discurso autoritário apresenta o desnivelamento entre as partes. Se um é dotado de autoridade para falar em nome de Deus, ele fala de um plano superior e imortal, ao outro resta o plano comum e mortal. É interessante observar que muitos pastores ganharam destaque em seu meio exatamente por assumir esse lugar de superioridade em relação aos fiéis. É o caso do

7 Orlandi, 1996, p. 242-243.

8 Citelli, 2004. 
pastor Valdomiro Santiago, fundador da Igreja Mundial do Poder de Deus, que se autodeclarou apóstolo e essa denominação lhe assegura maior prestígio por "ser um discípulo de Jesus Cristo" e, como tal, representante legitimo de suas palavras e ensinamentos. Quem, então, pode contestar as suas palavras?

Dessa forma, segundo Orlandi', o discurso religioso é marcado pela anulação da reversibilidade, ou seja, pela impossibilidade de interlocução, de dialogismo entre o pregador e seu auditório. Essa condição impõe grande distância entre o contexto da produção e o da recepção do discurso religioso, uma vez que estabelece de modo definido a separação entre os dois universos envolvidos.

Embora não haja reversibilidade de fato, é a ilusão de reversibilidade que sustenta esse discurso, "porque, quando esta é zero, esse se rompe, desfaz-se o contato e o objetivo do discurso fica comprometido. Daí a necessidade de se manter o desejo de torná-lo reversível ${ }^{10}$." E é essa ilusão de reversibilidade que se instala no discurso religioso. Durante os sermões, as indagações feitas pelo pastor passam a ilusão de que o auditório participa do ato retórico.

Não podemos negar que os textos bíblicos regem as instituições religiosas. No entanto, por mais que o discurso se mostre com estruturas rígidas, cada orador, mesmo sob o signo da instituição, constrói o seu discurso de maneira distinta para buscar um objetivo comum: convencer o auditório para a sua verdade. No caso do ato retórico da Pastora Damares, por exemplo, ao abordar o tema sobre ideologia de gênero, além de basear seus argumentos nos textos bíblicos, também expõe o seu ponto de vista sobre o assunto ao citar exemplos de sua vida particular para justificar sua tese. Não é à toa que os pastores mais conhecidos da mídia ganharam destaque pela maneira como constroem a argumentação em seus discursos.

\section{Os lugares retóricos}

O que devemos entender por lugares retóricos? Segundo Reboul ${ }^{11}$, esse termo é tão corrente quanto obscuro. Na dúvida, pode-se sempre traduzir "lugar" por argumentos. Sendo assim, resumidamente, entende-se lugares retóricos por argumentação, ou seja, o orador vale-se de sua fala, de seu discurso rico e amplo para adquirir a confiança do seu auditório.

9 Orlandi, 2006.

10 Orlandi, 2006, p. 244.

11 Reboul, 2004. 
Aristóteles (384-322 a.C.) distinguia os lugares-comuns e os lugares específicos. Os lugares-comuns se caracterizavam, primitivamente, por sua imensa generalidade, que os tornava utilizáveis nos três gêneros do discurso retórico (deliberativo, judicial e epidítico). Já os lugares específicos eram aqueles que tratavam de temas que são próprios de um determinado gênero retórico. Assim, o gênero deliberativo utiliza argumentos que se fundam na noção de utilidade, o gênero judicial argumentos que se fundam na noção de justiça e o gênero epidítico argumentos que fazem apelo a qualidades morais (virtude e vício) ou estéticas (belo e feio).

No entanto, para Cunha, "os lugares, sejam eles comuns ou específicos, têm uma função predominante nas premissas de qualquer argumentação uma vez que, por definição, são o tipo de argumentos relativamente aos quais o orador pode ter por assegurado o acordo do auditório ${ }^{12}$. Esse acordo já anteriormente teria sido estabelecido, senão esses argumentos não seriam lugares (topoi).

Embora Aristóteles fundamentasse sua filosofia em vários lugares retóricos, Perelman e Olbrechts-Tyteca ${ }^{13}$ conglobam itens de aspectos gerais: lugares da quantidade, da qualidade, da ordem, do existente, da essência, da pessoa.

Lugares de quantidade são entendidos pelos autores como os de lugares comuns que alguma coisa é melhor que a outra por valores quantitativos. A questão da superioridade é empregada tanto nos valores positivos quanto nos valores negativos. Segundo os autores, o lugar do quantitativo, do duradouro concede também a valorização da verdade, do seguro, do estável. Portanto, este lugar permeia ao que é concreto, estável, ou seja, do provável ao improvável, do fácil sobre o difícil, portanto, ao que não se corre o risco de escapar.

Em relação ao lugar de qualidade, Perelman e Olbrechts-Tyteca mencionam a respeito do habitual, o normal, utilizado com muita frequência e que, do normal à norma passa quase como sendo despercebida. Essa passagem é a dissociação dos dois e sua oposição mediante a afirmação da prioridade da norma sobre o normal, que necessita de uma argumentação que a justifique: essa argumentação tenderá à desvalorização do normal, o mais das vezes pelo uso de outros lugares que não os da quantidade. Mas tanto na quantidade quanto na qualidade, temos sempre um acordo sobre a situação de como

12 Cunha, 1998, p. 10.

13 Perelman e Olbrechts-Tyteca, 2014. 
cada um desses lugares é contextualizado e sobre a forma em que se dará o consenso entre auditório e orador.

Os lugares da ordem afirmam a superioridade do anterior sobre o posterior, ora da causa, dos princípios, ora do fim ou do objetivo; os lugares do existente afirmam a superioridade do que existe, do que é atual, do que é real, sobre o possível, o eventual ou o impossível; o lugar da essência refere-se ao fato de conceder um valor superior aos indivíduos enquanto representantes bem caracterizados dessa essência; o lugar da pessoa vincula-se à sua dignidade, ao seu mérito, à sua autonomia.

Assim, são a partir dos lugares retóricos que o orador toma conhecimento daquilo que os integrantes do auditório entendem como já pré-estabelecido e aceitável durante a argumentação. Nesses termos, qualquer argumentação pressupõe uma infinidade de objetos de acordo para se tornar efetiva.

\section{O discurso da Pastora Damares Alves}

O excerto a seguir faz parte do vídeo, originalmente publicado pelo perfil da comunidade católica Missão Maria de Nazaré, e mostra a Pastora Damares Alves em uma palestra, proferida em abril de 2018, sobre ideologia de gênero, intitulada: "A ideologia de gênero faz mal para a criança”. Com quase uma hora de duração, a pastora argumenta em seu ato retórico sobre o mal que a ideologia de gênero causa na vida de uma criança:

O desenho Frozen... A princesa Aurora vai voltar para acordar a Branca de Neve. O desenho Frozen eu assisti, é um desenho bonito, até cantei a música: "Livre estou, livre estou.... Por que ela termina sozinha no castelo de areia (de gelo)? Porque é lésbica! Nada é por um acaso. Gente eles estão armados, articulados. O cão é muito bem articulado e nós estamos alienados. Agora a princesa de Frozen vai voltar para acordar a Bela Adormecida com um beijo gay. Isso é muito grave! Sabe por quê? Eu fui menina e sonhei em ser princesa. Eu sonhei com o meu príncipe encantado. A gente está abrindo uma brecha na cabecinha da menina de três anos parar de sonhar com princesa. Isso aqui é indução.

A pastora Damares Alves profere o discurso com a finalidade de obter a adesão do auditório para a sua causa. Falando alto e gesticulando o tempo inteiro, cria um ambiente favorável ao seu discurso ao mesmo tempo em 
que constrói a sua imagem aos ouvintes. Como representante da Igreja, possui a legitimidade para falar em nome da Instituição religiosa e, assim, abordar temas polêmicos como a ideologia de gênero, homossexualidade, aborto, entre outros.

Pastora voluntária na Igreja Batista da Lagoinha, em Belo Horizonte (MG), uma comunidade evangélica que reúne cerca de trinta mil pessoas na capital mineira, Damares reúne cerca de seis mil pessoas nos cultos que ministra na cidade. Em seus sermões, costuma repetir a ideia de que a política não vai salvar a nação, mas sim a igreja evangélica e, assim, demonstra o desejo de regular ações de ordem moral.

A questão da ideologia de gênero é pautada por Damares em exemplos do universo do auditório e do orador. Ao citar que o desenho Frozen pode ser uma influência negativa para as crianças, busca a adesão daqueles que são pais e que se preocupam com a formação moral de seus filhos. É uma espécie de alerta para que todos percebam que o mal está em todos os lugares e que todos devem ficar atentos.

Esse fato reforça os preceitos de que os homens que não seguem os ensinamentos bíblicos podem ser influenciados por forças malignas. A oradora vê o sujeito como um ser que sofre, a todo momento, assédio por parte dos demônios. Sendo assim, é necessário que o fiel aceite o Evangelho e entregue-se a Deus para poder resistir. Para eles, a vida fora da igreja está tomada pelo mal, e as pessoas devem ficar atentas as artimanhas do mal.

Seguindo as características do gênero, seu discurso é autoritário e revela um tom de verdade inquestionável. A argumentação se realiza com tal grau de fechamento que não resta ao receptor qualquer dúvida quanto à verdade do que é dito. Não há reversibilidade do discurso, ou seja, não há espaços para o auditório responder às indagações feitas ou mesmo para questionar os argumentos

Além disso, para o orador todas as práticas e crenças da igreja são justificadas pela Bíblia, considerada a verdade absoluta por ser a Palavra de Deus. Por esse motivo, todas as ideias que alguma forma a contrariam são consideradas heresia. Seus adeptos, além de aceitarem a Bíblia como guia incontestável, propõem uma volta à tradição dogmática e moral e o fortalecimento da comunidade e da autoridade da Igreja.

No caso da ideologia de gênero, o discurso de Damares Alves provavelmente se pautou na criação da humanidade, uma vez que não há nada específico sobre esse tema: "E criou Deus o homem à sua imagem; à imagem de Deus o criou; homem e mulher os criou" (Gn 1.27). E ainda: "Ele, porém, respondendo, disse-lhes: Não tendes lido que aquele que os fez no princípio 
macho e fêmea os fez, e disse: Portanto, deixará o homem pai e mãe, e se unirá a sua mulher, e serão dois numa só carne?” (Mt 19.4,5). Não há, em nenhum dos 31.173 versículos da Bíblia, o reconhecimento da existência de outros sexos ou gêneros além de "homem" e "mulher".

Assim, para a pastora, a Igreja deve confrontar esse tipo de ideologia a partir das Escrituras, que diz que Deus criou o homem à Sua imagem e semelhança. Homem e mulher os fez, ou seja, a determinação biológica, sexual e genérica é feita no nascimento. Nós nascemos homem ou mulher.

Para obter adesão a essa causa, move-se o auditório pelas paixões, ou seja, pelo sentimento de proteção de um pai para seu filho. E a escolha do filme Frozen para exemplificar a questão, está relacionada ao universo infantil. Qual criança não assistiu a esse filme? E qual pai não cantou com os filhos a trilha sonora? Assim como fez a pastora antes de associar a mensagem ao movimento ideológico. A música possui um grau de encantamento que pode enganar as pessoas e, por esse motivo, deve ser combatido. Mais uma vez reforça a ideia das forças malignas tentando corromper o homem.

Além disso, durante o discurso, a oradora mostra algumas fotos que comprovariam sua tese. No entanto, essa foto não faz parte do acervo da Disney. A ilustração está no livro "A bela e a adormecida", escrito por Neil Gaiman, que tampouco é destinado ao público infantil. No entanto, a verdade dela prevalece e não há questionamentos sobre a veracidade dos fatos.

Neste trecho: "a princesa Aurora vai voltar para acordar a Branca de Neve. O desenho Frozen eu assisti, é um desenho bonito, até cantei a música: 'Livre estou, livre estou...". Ela deixa claro o lugar do existente. Afirma a veracidade do retorno da princesa Aurora. Coloca sua opinião quando diz que o desenho é bonito e ainda comenta que até cantou o tema do referido desenho. Com relação ao trecho, segundo Perelman e Olbrechts-Tyteca, persuade-se os ouvintes pelo logos quando por meio do discurso eles creem, quando mostramos o que é verdadeiro ou o que parece [verdadeiro] a partir das coisas que persuadem em relação a cada caso.

No trecho seguinte: "por que ela termina sozinha no castelo de areia (de gelo)? Porque é lésbica! Nada é por um acaso". Nota-se o lugar da ordem, em que a causa é superior aos efeitos. A oradora também se vale das provas lógicas para a construção de seu ethos. Em "Gente eles estão armados, articulados. O cão é muito bem articulado e nós estamos alienados”, a oradora usou o que chamamos de silogismo dialético ou entimema, que se refere aos provável, não estabelece a certeza, mas a probabilidade e a opinião ${ }^{14}$. $\mathrm{Na}$

14 Cf. Ferreira, 2010. 
parte seguinte, a oradora utiliza novamente o lugar do existente. Diz: "Agora a princesa de "Frozen" vai voltar para acordar a Bela Adormecida com um beijo gay". E, por fim, vale-se de provas intrínsecas, divididas em lógicas (os silogismos, os entimemas e os exemplos) e psicológicas (éticas e patéticas). De modo simples, as provas lógicas pretendem convencer (mover pela razão) e as psicológicas, persuadir (mover pela emoção) ${ }^{15}$.

\section{Considerações finais}

Com a clara finalidade de obter adesão de seu auditório, a pastora Damares Alves se vale de estratégias retóricas para criar um ambiente favorável ao seu discurso e ao mesmo tempo constrói sua imagem. Como oradora, Damares move o auditório pela constituição de um ethos confiável. Levar o auditório a aceitar o que é proposto é o foco central deste discurso estrategicamente elaborado de acordo com as características do gênero.

Há uma preocupação em se fazer entender pelo auditório. O orador valoriza o timbre; com o gestual; usa as pausas em momentos estratégicos. Enfim, todo esse conjunto não somente enriquece os recursos argumentativos no discurso, mas também coopera para atrair a atenção do ouvinte, que parece captar os argumentos de maneira mais viva e absorver as estruturas textuais de forma mais abrangente.

Percebeu-se que pela proximidade com o público, há no discurso proferido pela pastora testemunhos pessoais, que possuem força própria e espontaneamente fazem com que esse discurso se aproxime mais do auditório. Sendo assim, pudemos verificar que a aceitação dos conselhos que a oradora oferece ao auditório se ancora na caminhada conjunta de um sistema de técnicas detalhadas, modalidades argumentativo-persuasivas que são constitutivas desse discurso e reforçam ainda mais a persuasão por meio dos elementos retóricos analisados.

15 Id. 
A igreja como espaço retórico para o ato da pregação

e o fortalecimento do ethos do(a) pastor (a)

169

\section{Referências}

AMOSSY, R. Da noção retórica de ethos à análise do discurso. In: AMOSSY, R. (org). Imagens de si no discurso, a construção do ethos. São Paulo: Contexto, 2005.

ARISTÓTELES. Retórica. Trad, textos adicionais e otas Edso Bini. São Paulo: Edipro 1.ed. 2011, 1. Reimp, 2013.

BURITY, J. A. Religião, voto e instituições políticas: notas sobre os evangélicos nas eleições de 2002. In: BURITY, J. A; MACHADO, M. D. C. (Orgs.) Os Votos de Deus: evangélicos, política e eleições no Brasil. Recife: Fundação Joaquim Nabuco, Ed. Massangana, 2006, p. 173-213.

CITELLI, A. Linguagem e persuasão. São Paulo: Ática, 1997.

CUNHA, T. C. e. A Nova Retórica de Perelman. Lisboa: Universidade Nova de Lisboa, 1998. 18 p. Disponível em www.bocc.ubi.pt. Acesso em Agosto de 2019.

FERREIRA, L. A. Leitura e persuasão: princípios de análise retórica. São Paulo: Contexto, 2010. (Coleção Linguagem e Ensino).

GOMES, P. G. Midiatização e processos sociais na América Latina. XXXI Congresso Brasileiro de Ciências da Comunicação, INTERCOM, Natal, set.2008. http://www.intercom.org.br/papers/nacionais/2008/resumos/R3-0880-1.pdf>.

MACEDO, E.; OLIVEIRA, C. Plano de poder: Deus, os cristãos e a política. Rio de Janeiro: Thomas Nelson Brasil, 2008.

MAFRA, C. Os evangélicos. Rio de Janeiro: Jorge Zahar, 2001.

ORLANDI, E. P. A linguagem e seu funcionamento: as formas do discurso. 4.ed. Campinas, SP: Pontes, 2006.

PERELMAN, C.; OLBRECHTS-TYTECA, L. Tratado da Argumentação: a nova retórica. São Paulo: Martins Fontes, 2014.

REBOUL, O. Introdução à Retórica. São Paulo: Martins Fontes, 2004.

TORRESAN, J. L. A Manipulação no Discurso Religioso. Dialogia, São Paulo, v. 6. 2007. 
